\section{CLINICAL COMPARISON OF THIOPENTONE AND METHOHEXITONE}

BY

\section{J. G. WHITWAM, M.B., F.F.A. R.C.S. \\ AND}

J. M. MANNERS, M.B., D.A.

Department of Anaesthetics, the General Infirmary at Leeds

During the past seven years there have been over 8,000 attendances at the out-patient cystoscopy clinic at the General Infirmary at Leeds, the age of the patients ranging from 8 to 78 years. Nearly all these patients have received general anaesthesia for cystoscopy, retrograde pyelography, or passage of sounds. Wherever possible, thiopentone has been used as the sole anaesthetic agent, providing adequate operating conditions in most cases.

Initial observations on the pharmacology of methohexitone were made in the U.S.A. in 1956, and it was introduced into clinical practice in the United Kingdom in December, 1960. The formulae of the two drugs are:<smiles>CCCC(C)C1(CCC)C(=O)NC(=S)N([125I])C1=O</smiles>

Sodium 5-ethyl-5-(1-methylbutyl)-2thiobarbiturate. (Thiopentone.)<smiles>C=CCC1(C(C)C#CCC)C(=O)N([18OH])C(=O)N1C</smiles>

Sodium $a$-DL-1-methyl-5-(allyl)-5-(methyl-2pentynyl)barbiturate. (Methohexitone.)

The significant characteristics claimed for methohexitone as compared with thiopentone are greater potency (approximately threefold), shorter duration of effect, prompt and alert recovery, and fewer serious respiratory and cardiovascular side-effects. In addition, unlike thiopentone, extravascular infusion of the drug does not appear to be associated with any serious effects. It was decided to introduce the use of methohexitone into this out-patient clinic.

\section{Material and Methods}

One hundred male and 50 female patients were divided into equal groups by using methohexitone and thiopentone on alternate cases. All patients were examined and weighed before premedication with atropine $0.65 \mathrm{mg}$. intramuscularly 30 minutes prior to induction of anaesthesia. Patients walked into the clinic and were put into position on the table before induction.

Methohexitone was used in a $1 \%$ solution ; the initial intravenous dose of $1 \mathrm{ml}$. (10 mg.) per stone body weight $(1.57 \mathrm{mg} . / \mathrm{kg}$.) was supplemented by further doses of 2-3 ml. when required, and was injected at a rate of approximately $1 \mathrm{ml}$. in three seconds. Thiopentone was used in $2.5 \%$ solution, with an initial dose of $1 \mathrm{ml}$. (25 mg.) per stone body weight $(3.93 \mathrm{mg} . / \mathrm{kg}$.) supplemented by further doses of 2-3 ml., given at a rate of approximately $1 \mathrm{ml}$. in two seconds. An initial dose ratio, methohexitone to thiopentone of $1: 2.5$, was selected, to load the series against methohexitone in terms of recovery while giving the drug an advantage in terms of control of the patient during surgery.

The aim was to use only the intravenous agent, but in six cases adequate control could not be obtained without using unreasonable quantities of barbiturate, and a supplementary nitrous oxide-oxygen-halothane sequence was introduced. Anaesthesia, more correctly hypnosis, was classified into four grades with reference to the occurrence of undesirable movements during induction and instrumentation: grade I, no movement; grade II, slight movement not interfering with instrumentation; grade III, movement interfering with instrumentation; and grade IV inadequate control requiring inhalation sequence.

In the recovery period patients were regarded as conscious when they would respond to simple commands. The following times were observed: (1) duration of anaesthesia-between induction of anaesthesia and recovery of consciousness; (2) duration of instrumentation-between introduction and removal of instruments; and (3) duration of recovery-period between end of instrumentation and recovery of consciousness.

At the end of instrumentation patients were classified into three groups: (1) eyes open; (2) "safe "- eyes closed, but able to maintain an adequate airway without assistance ; and (3) " unsafe"-eyes closed, airway requiring assistance.

Observations were made on the pulse rate, systolic blood-pressure (obtained by occluding the radial pulse with a sphygmomanometer cuff placed on the arm), eyelash reflex (this was tested frequently throughout the procedure, and was recorded as abolished if at any stage it was found to be absent). The occurrence of cough, hiccup, laryngeal spasm, tremor, and other involuntary movements was recorded. Patients were further classified according to whether a satisfactory airway was maintained throughout anaesthesia without assistance, or whether assistance was required (by altering the position of the head or holding the jaw forward). One hour after recovery of consciousness patients were tested for the presence of Rombergism.

\section{Results}

Table I shows the duration of anaesthesia, instrumentation, and recovery together with the dosage of the two drugs. Those patients who required inhalational supplement were excluded from this comparison. On a purely weight basis methohexitone was less than three times as potent as thiopentone, but when the duration of anaesthesia was also considered methohexitone proved to be more than three times as potent.

Grades of Anaesthesia (Table II).--Those patients receiving thiopentone who did not fall into grade I exhibited either reflex movements of the limbs and eyebrows in response to surgical stimulation or respiratory upset such as cough or hiccup. The majority of patients receiving methohexitone developed clonic movements involving principally the hips, knees, and ankles, and in addition showed a greater incidence of respiratory upset. In the majority of patients further 
methohexitone failed to reduce the tremor. Of the five "failures" with methohexitone, one female and one male patient developed tonic contractions of the leg muscles, which did not diminish with further drug. Three males developed a severe tremor, which did not respond to further administration of methohexitone and which made cystoscopy impossible. This muscular activity ceased with the administration of nitrous oxideoxygen-halothane.

Condition at end of instrumentation can be seen from Table II.

Tremor (Table II).-None of the thiopentone group exhibited this phenomenon; 43 males and 10 females receiving methohexitone developed a tremor. The occurrence of reflex movements in response to stimulus was used as an indication for administration of more barbiturate, and, apart from the few who coughed or hiccuped, this type of movement accounted for grades 11, III, and IV of anaesthesia in the thiopentone group. In the methohexitone group further drug was administered in an effort to control not only reflex responses but also tremor when this occurred.

Respiratory Effects (Table II).-No patient in either group required assisted respiration, nor was oxygen administered except as part of an inhalational anaesthetic. In no case was an artificial airway required, except in those patients receiving halothane. No case of laryngeal spasm occurred in either group.

Cardiovascular Effects.-Pulse rate: initial rates were rapid, owing to a combination of atropine, anxiety, and exercise ; no consistent trends were observed. Bloodpressure (Table III): Those cases where the use of halothane became necessary were included in these results, because the significant changes in systolic pressure, due to barbiturate, were complete prior to the introduction of halothane. The effect of the drug on systolic pressure occurred after the induction dose. All patients receiving thiopentone showed a fall in systolic blood-pressure; of those receiving methohexitone, $44 \%$ showed no fall in systolic pressure, while in the remaining $56 \%$ the effect of the drug on the systolic pressure was comparable with thiopentone.

Effect on eyelash reflex can be seen from Table II.

Sequelae.-One hour after operation 38 males and 20 females who had been given thiopentone demonstrated Rombergism. This was seen in only five males and four females in the methohexitone group. At no stage did any of the patients in either group complain of nausea, and none was observed to retch or vomit.

\section{Discussion}

There has been no previous report of the use of methohexitone as the sole agent for out-patient anaesthesia, nor is there any previous report comparing the two drugs in patients premedicated with atropine alone and in the absence of any other anaesthetic agent.

Methohexitone was discontinued in the clinic because adequate control of the patients was not obtained with the drug. In $86 \%$ of the male and $40 \%$ of the female patients tremor of the lower limbs appeared, hindering instrumentation, particularly the passage of ureteric catheters. These movements accounted for the significantly longer duration of anaesthesia in the methohexitone group.

Muscle movements and tremor were not reported in the original observations of Stoelting (1957). There was an incidence of approximately $3 \%$ in a larger series reported by Taylor and Stoelting (1960), who found that additional amounts of methohexitone controlled the movements. A low incidence was reported by Redish et al. (1958) and by Weyl et al. (1958). Wyant and Chang (1959) reported an incidence of $35 \%$ of minor muscle movements in female patients premedicated with atropine and pethidine $(50 \mathrm{mg}$.) undergoing minor gynaecological surgery with methohexitone anaesthesia. This would appear to correspond to the $40 \%$ incidence of tremor with or without other involuntary movements reported in the present series of female patients. Dundee and Moore (196la, 1961b) and Moore and Dundee (1961), in three series of patients under-

TABLE I.-Dose of Barbiturate and Duration of "Anaesthesia." Male and Female Groups and Combined Male and Female Groups Comparable with Respect to Weight and Recovery Time $(t<1.0, P>0.30$, in each case). Duration of Instrumentation Significantly Longer in Methohexitone Group (male, $t=3.5, P<0.001 ;$ female, $t=4.1, P<0.001$ )

\begin{tabular}{|c|c|c|c|c|c|c|c|c|c|c|}
\hline \multirow{2}{*}{ Sex } & \multirow{2}{*}{$\begin{array}{l}\text { No. of } \\
\text { Cases }\end{array}$} & \multirow{2}{*}{$\begin{array}{l}\text { Mean } \\
\text { Age in } \\
\text { Years }\end{array}$} & \multirow{2}{*}{$\begin{array}{c}\text { Mean } \\
\text { Weight } \\
\text { (kg.) }\end{array}$} & \multicolumn{2}{|c|}{$\begin{array}{l}\text { Mean Total Dose } \\
\text { of Drug (mg.) }\end{array}$} & \multirow{2}{*}{$\begin{array}{l}\text { Mean } \\
\text { Duration of } \\
\text { Anaesthesia }\end{array}$} & \multirow{2}{*}{$\begin{array}{c}\text { Mean } \\
\text { Duration of } \\
\text { Instrumentation }\end{array}$} & \multirow{2}{*}{$\begin{array}{c}\text { Mean } \\
\text { Duration of } \\
\text { Recovery }\end{array}$} & \multirow{2}{*}{$\begin{array}{c}\text { Mean } \\
\text { Dose } \\
\text { (mg./kg.) }\end{array}$} & \multirow{2}{*}{$\begin{array}{c}\text { Mean } \\
\text { Dose } \\
\text { (mg. } / \mathrm{kg} \cdot / \mathrm{min} .)\end{array}$} \\
\hline & & & & $\begin{array}{l}\text { Thio- } \\
\text { pentone }\end{array}$ & $\begin{array}{l}\text { Metho- } \\
\text { hexitone }\end{array}$ & & & & & \\
\hline $\begin{array}{l}\mathrm{M} \\
\mathrm{M} \\
\mathrm{F} \\
\mathrm{F}\end{array}$ & $\begin{array}{l}49 \\
46 \\
25 \\
24\end{array}$ & $\begin{array}{l}59 \\
50 \\
36 \\
44\end{array}$ & $\begin{array}{l}68 \cdot 2 \\
68 \cdot 7 \\
57 \cdot 3 \\
60\end{array}$ & $\begin{array}{l}500 \\
375\end{array}$ & $\begin{array}{l}180 \\
150\end{array}$ & $\begin{array}{rrrr}11 & \min . & 15 \mathrm{sec} . \\
12 & , & 46 & \\
6 & , & 50 & , \\
9 & , & 23 & ,\end{array}$ & $\begin{array}{llrr}6 & \text { min. } & 15 & \text { sec. } \\
8 & , " & 3 & ., \\
3 & , " & & \\
5 & ., & 37 & \text { s?c. }\end{array}$ & $\begin{array}{llll}3 & \min & 44 & \text { sec. } \\
3 & , & 17 & \text {. } \\
3 & , & 20 & , \\
3 & , & 15 & , "\end{array}$ & $\begin{array}{l}7 \cdot 3 \\
2 \cdot 6 \\
6 \cdot 5 \\
2 \cdot 5\end{array}$ & $\begin{array}{l}0.65 \\
0.20 \\
0.96 \\
0.27\end{array}$ \\
\hline
\end{tabular}

TABLE II.-Comparison of Some Features of Thiopentone and Methohexitone "Anaesthesia"

\begin{tabular}{|c|c|c|c|c|c|c|c|c|c|c|c|c|c|c|c|c|}
\hline \multirow[t]{2}{*}{ Sex } & \multirow{2}{*}{ Drug } & \multirow{2}{*}{$\begin{array}{c}\text { No. } \\
\text { of } \\
\text { Cases }\end{array}$} & \multicolumn{4}{|c|}{ "Anaesthesia" } & \multicolumn{3}{|c|}{$\begin{array}{l}\text { Condition at end } \\
\text { of Instrumentation }\end{array}$} & \multicolumn{2}{|c|}{ Tremor } & \multirow{2}{*}{$\begin{array}{c}\text { Airway } \\
\text { Requir- } \\
\text { ing } \\
\text { Assistance }\end{array}$} & \multirow{2}{*}{$\begin{array}{c}\text { Lash } \\
\text { Reflex } \\
\text { Abolished }\end{array}$} & \multirow{2}{*}{ Cough } & \multirow{2}{*}{ Hiccup } & \multirow{2}{*}{$\begin{array}{l}\text { Rom- } \\
\text { bergism } \\
1 \text { Hour } \\
\text { Post-op }\end{array}$} \\
\hline & & & I & II & 'III & IV & 1 & 2 & 3 & Mod. & Sev. & & & & & \\
\hline $\begin{array}{l}\mathbf{M} \\
\mathbf{M}\end{array}$ & $\begin{array}{l}\text { Thiopentone .. } \\
\text { Methohexitone }\end{array}$ & $\begin{array}{l}50 \\
50\end{array}$ & $\begin{array}{r}32 \\
7\end{array}$ & $\begin{array}{l}11 \\
27\end{array}$ & $\begin{array}{r}6 \\
12\end{array}$ & $\begin{array}{l}1 \\
4\end{array}$ & $\begin{array}{l}23 \\
35\end{array}$ & $\begin{array}{l}22 \\
15\end{array}$ & 5 & $\overline{40}$ & $\overline{3}$ & $\begin{array}{r}30 \\
8\end{array}$ & $\begin{array}{l}47 \\
12\end{array}$ & $\begin{array}{l}1 \\
2\end{array}$ & $\frac{2}{4}$ & $\begin{array}{r}38 \\
5\end{array}$ \\
\hline$\stackrel{F}{F}$ & $\begin{array}{l}\text { Thiopentone } \\
\text { Methohexitone }\end{array}$ & $\begin{array}{l}25 \\
25\end{array}$ & $\begin{array}{l}19 \\
15\end{array}$ & $\begin{array}{l}6 \\
8\end{array}$ & $\overline{1}$ & $\overline{1}$ & $\begin{array}{l}13 \\
14\end{array}$ & $\begin{array}{l}12 \\
11\end{array}$ & 二 & $\overline{9}$ & $\overline{1}$ & $\begin{array}{r}10 \\
3\end{array}$ & $\begin{array}{r}18 \\
5\end{array}$ & $\overline{1}$ & $\overline{1}$ & $\begin{array}{r}20 \\
4\end{array}$ \\
\hline
\end{tabular}

TABLE III.-Comparison of Thiopentone and the Two Methohexitone Groups

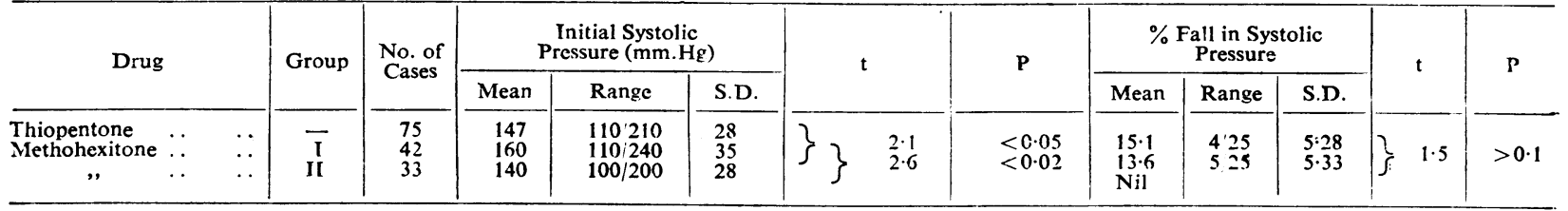


going minor gynaecological surgery premedicated with atropine, using intermittent methohexitone supplemented by nitrous-oxide anaesthesia, reported incidence of tremor in $22 \%, 17 \%$, and $22 \%$ of cases. In two of their series equal numbers of patients were given thiopentone, and in these patients the incidence of tremor was zero, as in the present study.

In the majority of patients receiving methohexitone the eyelash reflex was present after induction at a level of narcosis which permitted instrumentation. In most patients receiving thiopentone the eyelash reflex was abolished after induction, returning later during instrumentation. Some anaesthetists use the abolition of the eyelash reflex as a guide to the induction dose of thiopentone. We are of the opinion that if this sign is used to assess the induction dose of methohexitone unnecessarily large doses of the drug will be given.

The incidence of cough and hiccup was remarkably low in this series. Previous reports indicate that a higher incidence of these complications is to be expected with methohexitone than with thiopentone.

Assistance with the airway was required less often with methohexitone than with thiopentone. No respiratory measurements were made in this series, and no conclusions were drawn regarding the relative effects of the two drugs on respiration. Reference to the literature does little to clarify this point, much depending on premedication, dose, and speed of injection.

There are remarkably few reports on the comparative effects of thiopentone and methohexitone on the circulation. From the present study it would appear that there is a lower incidence of hypotension with methohexitone than with thiopentone. However, in those patients receiving methohexitone in which a fall of systolic pressure did occur, this was of the same order as in those cases receiving thiopentone. It is of interest that the initial mean systolic pressure in the methohexitone group which showed a fall in pressure was significantly higher than in the group showing no such fall.

In the present study the awakening time, as judged by the ability to respond to simple commands, was the same for the two drugs, but one hour after operation there was a marked difference between the two groups of patients. The majority of patients who had received methohexitone were ready to go home; only a few were resting and still fewer were unsteady on their feet, as judged by the ability to stand erect, with the eyes closed and the feet together. The majority of patients in the thiopentone group still showed Rombergism and had the usual "hangover" associated with the drug. Some of those patients to whom thiopentone had been administered on previous visits to the clinic, and who had been given methohexitone, volunteered that they had not felt as clear-headed after previous anaesthetics; these patients were unaware that a different agent had been used.

The absence of hangover is one of the striking features of the use of methohexitone, and in many previous reports a shorter awakening time has also been noted, as compared with thiopentone.

We are of the opinion that the occurrence of induction complications with methohexitone after premedication with atropine should not be a major disadvantage to its use. Dundee and Moore (1961b) have previously expressed this opinion. When using a potent agent with a short duration of effect like methohexitone it is difficult to avoid "swinging anaesthesia" during intermittent administration. This factor, combined with a higher incidence of side-effects, makes methohexitone less satisfactory than thiopentone when used in this way as the sole anaesthetic agent. As an agent for induction of anaesthesia, methohexitone would appear to be preferable to thiopentone in cases where rapid recovery free from hangover is desirable and where hypotension during induction is to be avoided.

There appears to be a qualitative difference in the action of the two drugs in that during instrumentation those patients receiving methohexitone were at a lighter plane of "anaesthesia" as judged by the eyelash reflex, and the ability to maintain an airway without assistance, compared with patients receiving thiopentone.

It should be stressed that the reason for discontinuing the use of methohexitone in the clinic was the appearance of clonic and tonic muscular activity of the lower limbs, when in the lithotomy position, which did not respond to further administration of methohexitone. It is of interest that this muscular activity disappeared immediately when nitrous oxide and halothane were introduced.

\section{Summary}

The use of methohexitone and thiopentone as sole anaesthetic agents in 150 out-patients at a cystoscopy clinic is described. The greater potency of methohexitone was confirmed. Qualitative differences in the activity of the two drugs were observed. Methohexitone was found to be associated with a higher incidence of cough, hiccup, and involuntary movement, but produced a smaller incidence of lowering of the systolic bloodpressure. While the immediate awakening time with the two drugs was the same, complete recovery as demonstrated by the absence of Rombergism was more rapid with methohexitone.

Acknowledgments are due to Professor L. N. Pyrah and Mr. F. Raper, on whose patients these observations were made ; to Miss G. Harrison for her helpful criticism; to Dr. J. Norman, Dr. S. Pinder, Sister G. Hodgson, and Sister P. Henson for their assistance in making the observations : and to Eli Lilly and Company Ltd. for information about methohexitone.

\section{BIBLIOGRAPHY}

Barron, D. W., and Dundee, J. W. (1961). Brit. J. Anaesth., 33, 81 .

Bellville, J. W., Fennel, P. J., Murphy, T., and Howland, W. S. (1960). J. Pharmacol. exp. Ther., 129, 108.

Chernish, S. M., Gruber, C. M., DeMeyer, M., Littlefield, S., and Stoelting, V. K. (1956). Fed. Proc., 15, 409.

Coleman, J., and Green, R. A. (1960). Anaesthesia, 15, 411.

Dobkin, A. B., and Wyant, G. M. (1957). Canad. Anaesth. Soc. J., 4, 295 .

Dundee, J. W., and Moore, J. (1961a). Anaesthesia, 16, 50.

Lundee, J. (1961b). Ibid., 16, 194.

Riding, J. E., Barron, D. W., and Nicholl, R. M. (1961). Brit. J. Anaesth., 33, 296.

Gibson, W. R., Doran, W. J., Wood, W. C., and Swanson, E. E. (1959). J.' Pharmacol. exp. Ther., 125, 23.

Green, R. A., and Jolly, C. (1960). Brit. J. Anaesth., 32, 593.

Gruber, C. M., Stoelting, V. K., Forney, R. B., White, P., and DeMeyer, M. (1957). Anesthesiology, 18, 50 .

Heaton, C. E. (1956). Curr. Res. Anesth., 35, 522

Moore, J., and Dundee, J. W. (1961). Anaesthesia, 16, 61

Redish, C. H., Vore, R. E., Chernish, S. M., and Gruber, C. M. (1958). Oral Surg., 11, 603.

Stoelting, V. K. (1957). Curr. Res. Anesth., 36, No. 3, p. 49.

Taylor, C., and Stoelting, V. K. (1960). Anesthesiology, 21, 29.

Weyl, R., Unal, B., and Alper, Y. (1958). Surg. Gynec. Obstet., 107, 588.

Wyant, G. M., and Barr, J. S. (1960). Canad. Anaesth. Soc. J., $7,127$.

and Chang, C. A. (1959). Ibid., 6, 40.

Dobkin, A. B., and Aasheim, G. M. (1957). Brit. J.

Anaesth., 29, 194. 